\title{
The Haunted Discipline: On the Political Nature of Folklore and the Political Destiny of Its Study
}

\author{
FABIO MUGNAINI \\ Department of Anthropology, University of Siena
}

\begin{abstract}
Referring to Italian examples, the paper focuses on the resilient concept of folklore as an objective and given set of cultural expressions, that has been haunting the discipline since its inception under the Romantic approach, and characterized the use that totalitarian regimes had been making of it. Since the second half of the last century, however, folklore scholarship could count on newer perspectives, drawn on the systematization of Gramsci's legacy, which frankly addresses its socio-political nature, and, by extension, the political relevance of its scholarship. Such a peculiar approach needs to be reconfirmed today, so as to cope with the returning temptations of a neutral approach within the contemporary heritage turn.
\end{abstract}

Keywords: Gramsci's legacy, cultural heritage turn, engaged folklore, political approach, Italian folklore studies

\section{A PERMANENT QUESTION}

It wasn't a surprise to discover, in the wide range of topics that had been selected for the XII Sief congress panel program - in addition to so many novelties or emerging themes - a classic one like the close relationship between folklore and politics. A little bit more surprising was the question mark, which apparently questioned the political nature of folklore studies; this was sufficient to move me to submit a provocative questioning of the panel itself (how could it happen that such a question was still circulating?). However, once at the conference, and even more during the panel presentation, my worries mostly faded out: politics was rather well represented and spread almost all over the new-entry topics, as well as the classic ones (archives, rituals, festivals...). The real surprise was, instead, the breath of fresh air that the three convenors brought to the panel session, starting from the mere objective consideration of their youth: it was to a person an entire generation younger than mine that I presented my resentful remark on how 
it could happen that the political nature of folklore studies was still put under question! I had been expecting a debate between the Marxist nostalgia of strategic allegiance between social scholars with organized political forces and supporters of postmodern relativistic, introspective, reflexive turn, or, alternatively, an illuminating survey on the various ways of being politically fashionable (from the perspective of cultural studies, post-structural studies, subaltern studies, etc.); both cases often stuck on a general theoretical stance, both of them far distant from the confrontation with the public use of social science results and skeptical about the contribution of its insights to the growing of a critical conscience.

Instead, the concept behind the panel proposal ("the idea of a publicly engaged anthropology") was, there, reintroduced as an urgent question by three young anthropologists, active in their own respective countries and elective collectivities, who were soliciting from the panel participants a nonrhetorical answer: whether that idea was to be definitively abandoned as a "naive conception, impossible to implement" or whether it could still be a "guiding principle" or a "motor for change". It was not a "school debate", the rhetorical formulation delivered the need of a confrontation on actual scholarly practices, conceptions, and public positions, and it seemed to me - as one of the elders amongst the participants - that I had the responsibility of taking that stance declaring my personal answer, as a researcher and teacher in the field of folklore, from the declining season of folklore revival to the present era of its transformation into Intangible Cultural Heritage, in Italy and from the perspective of its peculiar political and cultural history (or chronicles).

\section{FOLKLORISTS: GOOD FOLK!}

Even the least up-to-date and informed of teachers would suggest to start looking for the answers already given. Few topics have been treated so often as the folklore/politics couple: amongst the more recent is the enduring effort by Stephen Olbrys Gencarella (Gencarella 2011, 2009) to set up a theoretical frame for a "critical" turn in folklore studies; however the matter is complicated by a triple bind: the historical and cultural background of the country from which the analysis is proposed, the ongoing political course and the hopes that the analyst has, consciously or not.

Just as any "critical research [should be] local and timely in scope, attuned to contingencies and exigencies, and thereby accountable to standards of judgments that correspond to those of context rather than universal formation", as Gencarella says (ibid.: 262), to reflect on it from a former communist 
country is rather different than doing the same from an old democracy like the USA, or the United Kingdom, or from a country like Italy, where, after the fascist era, the dream of a revolution and the collaboration with the main Western communist party, has involved the policies of folklore discovery and valorization; the matter changes as well if we consider it from the ceiling perspective of international institutions (like Unesco) or from the regions which are redefining their relationship with the respective national entities (Catalunya, Scotland, the Northern Italy among others). Notwithstanding its ongoing presence and its variable designation (it is sometimes presented as engagement/disengagement, or advocacy/scholarship, and, of course, public folklore/academic folklore), folklore-politics remains a controversial binomial: some may think of it as an oxymoron, others as a hendiadys. Jumping from one stone to another, as in crossing a creek, or surfing on an inexhaustible theme as it is, I'll try to offer the answer that I've personally found, adopted and reproduced, as a folklore researcher and teacher.

In any of the previous pairs one thing is taken for granted: the political birth of folklore studies; until the first half of the $20^{\text {th }}$ century, according to Linda Dégh:

the study of culture - whether anthropology or folklore - has always been political. It is no accident of history that the concept of folklore was born at the same time as the concept of nationalism, both serving the independence of oppressed nations. Everyone has known since the Grimms that folklore is politics. (Dégh 1999: 527)

The occasion for this high-sounding statement is a minor but vivid debate that was ignited by a remark by Jo Ann Conrad (Conrad 1998), who reported an event of openly political control over folklore topics: during an international conference organized by the Turkish government on Nasreddin Hoca, the contributions which diverged from the celebration of this narrative feature as a national hero (hers and Ilhan Basgoz 's), i.e. not in accordance with the view of a revanchist traditional and confessional Turkish identity, had been fiercely contested and silenced by the audience as well the organizers. Conrad, then, developed a rhetorical question: if the divergent readings of folklore items are so badly hindered by leading political forces when they are officially accredited, fostered, or even silently accepted, would this indicate complicity, collusion or, at least, insignificance?

The debate went on (Basgoz 2001), and even encompassed judgments on the quality of prominent folklore scholars' work that were too sharp; but we can still consider some of Dégh's statements as exemplary of a practicebased conception: instead of "empty metadiscourse over something we already realize - that the study of culture is political (such as Conrad's claim, 
in Dégh's view) - folklorists should refer to good examples, such as Henry Glassie's and her own (ibid.: 528).

As for her own work, the milestone research on Folktales and Society (1960), is proposed as exemplifying the necessary equilibrium between the critical depiction of the political context ("the bigger picture") and the accuracy of a respectful attitude when getting closer to the ethnographic field, especially when folklorists "are doing research in a foreign country": then "it is misguided [...] to get into politics and be involved in explaining their political opinions" (ibid.: 527). More generally

fieldworkers are not educators, not saviors, not missionaries, not politicians. They are observers. They must appear as students of culture and give up their own personal opinions and ethnic prejudices. And they must accept and look at what they see as the status quo. They can note controversies, but they cannot involve themselves. They must collect and learn but they must never interfere. They should never disagree or discuss situations adversely. (ibid.: 528)

In Degh's eyes, Henry Glassie's work deserves a mention as "he makes friends with everybody. And he produces substantial books recognized by the countries - including Turkey - that feel honored for having their folk art introduced to the world by him" (ibid.). Indeed, Henry Glassie is an example of a tightrope walker: "Passing the time in Ballymenone" (Glassie 1982) is a monumental quasi-monography produced after repeated and prolonged fieldwork in an Ulster county, mostly in the 1970s, when urban Ulster was set ablaze by the euphemistically labeled "troubles". Glassie examines the rural texture of Ulster, as a believer in a dialogic and constructivist conception of ethnography. There were no objects to dig for, but a social reality to bring to coalescence for the academic community, and, more importantly, for "Ballymenone's people of the future [who] will find [in his book] the texts they will need to understand their place, the texts they would have gathered themselves had they gotten the chance that [he] did" (Glassie 1982: xiii).

Henry Glassie clearly spelt out - in the preface to the final book published in 1982 - the double nature of the folklorist, who is indebted as much to scholarship as to the whole of society:

Scholars are citizens, in debt to their society. Our study must push beyond things to meanings, and grope through meanings to values. Study must rise to perplex and to stand to become part of a critical endeavor. We study others so their humanity will bring our own into awareness, so the future will be better that the past. The others I studied and choose to describe to you do not occupy some misty island from distant days. They live in a hard corner of the same world you and I inhabit. Money is scarce there, work is ceaseless. Their 
skies crack with storms and pound with bombs. Ulster. The sacred heart of their community has been split by political terror. Despite it all, they remain good people. We have much to learn from them. (ibid.: xiv)

There are many definitions of politics here: a general (and generic) enhancement of conscience, a selection of exemplary values, the salvaging of a heritage put at risk by external forces, and the possible production of a new political identity for the forthcoming generations.

Henry Glassie's work is centered on the religious dichotomy which, in those years, was synonymous with Ulster, but to prove that seen at the closest possible distance people were not divided. Much of his effort to understand aims to free religion from the guilt of so much violence (ibid.: 302), to absolve the local people and their respective confessions from any responsibility ("Protestants and Catholics do not have different versions of history. They have different histories", 153) and to highlight the values of the social texture of the local community:

Despite the Troubles, because of their impossible complexity, neighborly accord prevails. Deep ideological differences are overarched in real contact. Formal conduct is framed that recognizes differences, then holds them apart while life goes on. Daylight dealings remain cordial. Though tightening, ceilis [the traditional wakenings] have not contracted into political purity. Loyalty to their own side does not compel people into disloyalty to their neighbors. (ibid.: 152)

Neighborliness is the core concept; ceilis is the traditional gathering that feeds the feelings and discourse of belonging, methal is the institution that guarantees to everybody an extraordinary collective work in case of emergency; and politics, the political use of religion, capitalism, the colonial presence of the British armies are amongst the external causes that threaten the local community and put the future Ballymenone generations in the risky condition of being obliged to read about them, instead of finding this social system still functioning. "Neighborliness is a political concept" (ibid.: 292). Henry Glassie's masterpiece shows how politics is ever present, sprouting up from the observation of local social practices without the lenses of the higher and distant political factions. However, the "impossible complexity" of the Ulster conflict can hardly be reduced to the sharp distinction between the good (the local community) and the bad (the external forces): "I do not know Belfast, but I know Ballymenone" (ibid.: 300). I wonder if it suffices that anthropology stops at knowing the second, and does not aim also to investigate the first. Bad guys should be there somewhere; the heritage that new Ulster generations have to deal with cannot separate the green hills of 
Ballymenone from the grey roof of the Maze, the prison of Longkesh (Graham and McDowell 2007). Isn't such an ecumenical view a way of locating politics outside of its proper field? Weren't there - let's also consider the times some nuances of folk community harmonic views, some crumbs of nostalgia for an Arcadian "original" village? Maybe politics must be intercepted at the proper level: too far away, and it will apparently encompass everything, too close, and it will disappear or fade into generic considerations (power, capitalism, ethics...). The encounter between the scholarly practice and the political field, sometimes, happens when history - and, consequently, political processes - is lacking.

\section{TELLING THE TRUTH}

This specific argument leads me to pay homage to Dunja Rihtman, one of the re-founders of modern Croatian ethnology, whom I met and became friendly with while I was a student in Siena, where Pietro Clemente - my professor of history of popular traditions - invited her regularly from the 1990s onwards. Though most of Dunja Rihtman-Auguštin's works would remain closed to me for linguistic reasons, her relationship with Siena's anthropological school was so special - and Dunja's speech so outstanding in her Croatian and Mittelereuropean scented Italian - that in Siena we all felt familiar with her studies. I owe to her, for instance, the suggestion of Bausinger's seminal works; we discussed her analysis of the changes affecting women's day in a changing ideological frame; I still remember how we felt surprised by her sensitivity to the identity needs of the Croatian nation: we, the (then) young Italian communist or left-oriented students, obliged by her personal history to face the growing wave of identitarian policies. In our little country, the identitarian turn of politics still sounded like a braggart's claim, Dunja Rihtman-Auguštin's lectures forced us to take it seriously. When I visited Zagreb, in the early spring of 1992, I learnt, from Dunja as well as from several other colleagues of the Zagreb Institute of Folklore, how hard it may be to continue with the lessons of history as persons, as citizens and as scholars as well. And how many different faces - or masks - may be assumed because of the political side of social life. On March $22^{\text {nd }} 2000$, Dunja Rihtman-Auguštin, during her last visit to Siena, summed up her relationship as ethnologist with the political domain in the following way:

In my family, as I remember from my childhood, we always used to talk about politics. It was a bourgeois family, not involved in politics, but interested in it, until when politics eventually got interested in us: the war came and at a given moment during World War II, seven components of my grandfather's 
family were internees at the Risiera di San Sabba, in Trieste (the prison that served as a starting point for the concentration camps). So politics was dealing with us. Then, after prison, we took part in the fight against fascism - here again politics within our lives. After the war, peace. I began to study again and chose ethnology. In ethnology, you know, not even the first letter of the word "politics" could be pronounced! [...] Croatian ethnology, as many other Eastern Europe ethnologies in those times, didn't treat politics for at least two reasons: first, a scientist has to have political integrity, but the scientist's political ideas could not get mixed up with scientific work; the second reason is that my professors of the 50s or 60s - and even before, since the 40s [...] feared that politics could exert pressures on ethnology - and indeed in the Soviet Union there had been a debate about the abolition of ethnological theory [...] so that Croatian ethnology didn't take political reasoning into consideration [...]. During the 1990s, when politics again started to be interested in its citizens, I said "stop: now I'm going to interpret"! And on one hand, to interpret the political symbology or political events happening around me, helped me to understand what was going on, and on the other, it helped me to obtain that intellectual integrity that was the dream of our ancestors. (my transcription, translation and excerpt from an integral video recording, Rithman-Auguštin, 2000)

Dunja Rihtman-Auguštin's thought may be even better understood in her own written formulations, thanks to the posthumous essay collection that Jasna Čapo Žmegač edited in 2004 (Rihtman-Auguštin 2004). Many threads there could be pertinent to the 2015 Zagreb panel: starting from the critics to the divide between folklore, or ethnology, and anthropology - that is no longer acceptable at the present-time (ibid.: 121) and that, fortunately, the Zagreb conference seemed to confirm.

Re-thinking the distancing of ethnology from politics, Dunja RihtmanAuguštin compared two positions: neutrality (distancing and objectivist) and criticism (subjectivist and militant), namely Roy D’Andrade vs. Nancy Scheper-Hugues (ibid.: 51-54), who reach a final and precise position: "all ethnology, including Croatian ethnology, can no longer at the beginning of the third millennium close its eyes to the force of power relations" (ibid.: 55).

This is another turn, in the concept of politics: politics as power relations, as a matter of fact for social relationships and for cultural expressions; power relations provide the ethnologist with a new task of "telling the powerful the truth to their faces" (ibid.: 56); we are far from the idea of folklore as some matter lying somewhere, to which well-trained scholars may give value and may read either pro or contra the interests or the discourses of political leaders. Neither folklore nor ethnology may be thought of without being framed in a wider power relationship. After the history lessons of the last decades of the twentieth century, which Dunja Rihtman-Auguštin synthetizes in her last reflections, without wanting to sound disrespectful, I would maintain that is not possible to properly understand Ballymenone without comprehending 
Belfast. Not any longer, if ever. The choice between political engagement or a distant respectful attitude, that Linda Dégh located at the level of folklorists' behavior, has deeper roots: politics is the domain where the power relations that gave birth to folklore as a specific cultural product (the necessary substance of nations), fuse and interact endlessly with the same forces that orient, suggest, influence and decide on the everyday life (and the future), first, of "folklore bearers", then of folklore consumers, and today, of folklore heirs. The main question should be, then, not "if" folklore studies may be politically relevant, but how have we - the disciplinary common sense - accepted the idea that they may not be politically relevant. This is the question that haunts folklore scholarships, more than many emerging fields of contemporary anthropology, and which we have inherited untouched today.

\section{NEEDLESS TO SAY; USEFUL TO STRESS}

How did it happen that folklore survived and even flourished free from (or deprived of) its political content? One part of the answer may be found in the origins. Writing on the history of Italian folklore scholarship, Alberto M. Cirese (Cirese 1971, 1974) identified some premises: the enduring attention of religious institutions to the thoughts, words, deeds and omissions of the folk, with the aim of evangelizing and warding off the devilish and heresy; the passion for history of intellectuals that would read their contemporary peasants as the bearers of crumbs of glorious past history, destined to be the seeds of a future nation; political institutions in need of knowing the people that they rule (the questionnaire of the Académie Celtique as a cultural census in the few years of Napoleonic power). The cumulating history of self-promoted and self-centered folklore attention, starts with Niccolò Tommaseo - another man bridging the two sides of the Adriatic sea. Here Dégh's argument of the twin birth of nation and folklore is confirmed, though not perfectly adhering to the historical process: the study of folklore is a premise, more than an effect, of a national birth. Of course, nationalism is the political and cultural humus, as well as the economic near horizon. But the first moves toward the folk precede the birth of the Italian nation. Amongst Tuscan mountain dwellers, in 1832, Tommaseo found a living and pure spring of an Italian artistic vein, i.e. an enduring cultural trait, above any political claim. Sung as songs, listened to and collected as poetry, the Tuscan voices joined all the other irredentist regions: "Canti popolari toscani, greci, illirici e corsi", that's the title of the first Italian folklore collections (1841-42). After him, many others followed, and some of them - like Giuseppe Tigri - started to voice the need of selecting the people to listen to, and of course their cultural products and voices, so as to keep the purity of that pure spring of 
beauty and morality. Bad manners of the urban vulgus, that could be met in the outskirt of Florence, culturally contaminated by the town's mood and sensitive to the political discourses, were waiting in ambush. Politics was outside the folk, not inside it. Others discussed it too, and the debate on the possible diverging readings of people's poetical expressions is well represented by Giuseppe Tenca (Cirese 1971: 146-150), who aggressively maintained the requirement to acknowledge how love lyrics were woven on a warp of social tensions: seasonal labors and abandonment; malaria and hunger. But his "realistic" readings did not succeed in replacing the prevalent ideological representation of the neo-Italian folk. The newborn nation, though old and well rooted in the dream of Italian artists and intellectuals, needed to euphemistically rephrase the difficult domination of the different regional or local folks, and the romantic vision proved to be still useful. In addition to this, rather soon after the unification and the settling of the Italian monarchy as the new regime (sometimes at the price of violent repression of regional outburst or of social protests), the folk received the first concrete and tangible signs of the new rule: a passport which allowed hundreds of thousands of neo-Italian citizens to leave their newborn state. Italy would enjoyed their remittances from afar, and would repay them with the guarantee that nothing would change in the abandoned country. Folklore was, at this point, part of this untold contract.

However, to reach what is a striking and paradoxical example of the "depoliticization of folklore", we have to jump to the use of folklore by the Fascist regime: once the climb to the political institutions was completed, the Fascist party headed to control the masses, starting with the school and with the control of the marginal peasant and local cultural expressions: Stefano Cavazza is the historian who did the risky job of identifying the complicity between fascism and folklore scholarship (Cavazza 1987, 1997); this part of national and disciplinary history is widely common to German nations and volkskunde (Bendix 1997), but leaving apart the Opera Nazionale per il Dopolavoro, and festival revivals or creations, or the creation of a new fascist calendar, I will concentrate on a tool for disciplining the masses - and the folk - which is as efficient as it is apparently minor, or inoffensive, so much so that it survived the fascist regime and brought the old (outdated) message into the following new democratic and republican era.

Though younger, I'm amongst those who remember - as does the philosopher Gianni Vattimo, who wrote about it in a newspaper note in 2008 - a small wall poster that could still be seen in the 1960s hanging in the most popular inns or taverns, or on the wall in places of popular socialization, such as backrooms of general stores, where people used to gather to drink and play cards. "Qui non si bestemmia, non si sputa per terra e non si parla di politica”. Here people don't curse, don't spit on the ground and don't 
talk of politics. The Fascist regime made much use of phrasal propaganda: Mussolini's sentences were handwritten in gigantic font size on external walls overlooking crossroads and squares and exerted a function of public, monumental warning. The small poster penetrated the interior of intimate everyday social life reaffirming a basic notion, aimed at every single conscience. Many other posters were warnings against specific behaviors: on one, collected in the Marche region, the message was directed at the peasants during threshing time, warning them "not to drink too much, not to sing subversive songs, not to wear red garments or even red flowers, not to speak of politics; not to insult fascists and fascism and to respect the government and its institutions", but this open political content - like the racist warning forbidding Jews entrance to public venues or preventing Slovenian people from speaking their language in the occupied Istrian territories - was eradicated as soon as the fascist regime fell; the one that I mentioned, instead, proposed a weird alliance: the anti-blasphemy campaign (a historical battle that the Savoia monarchy endorsed so as to show its loyalty to the Roman Catholic authority), the hygienic imperative not to spit, which was at the same time a civilizing tool and, ad adiuvandum, a way of fighting against tuberculosis: the so-called subtle disease that was rooted in poor living conditions, but was fought by promoting good manners and hygienic precepts. Finally politics: to speak of politics could mean, during the regime, to speak against or to stimulate possible antifascist attitudes, so as to suggest that the political consensus was, by nature, a debatable question.

Just as God's name and human health are absolute values taken for granted, so too the political order must be considered: others, elsewhere, will deal with it; lay persons are prevented from doing it publicly. Political doubt and criticism should die in the intimate and speechless individual consciences.

Together with other slogans (don't disturb the driver - so cherished by the last Italian political leaders), the lesson of the Fascist regime was simple: the handover of power to the specialist, and blinding people to the truth in their action, until the political order was considered a natural - or a divine one. This has not lost its effect. Though passionate and often vociferous political speakers, Italians did learn from those times that speaking of politics is equivalent to criticizing the political order, while appreciating it or being aligned with it is not to take a political stance. The political order itself is status quo, and as such it aims at the givenness of the real reality (not utopia), at neutrality (not factionalism of the opponents): its ideological nature is concealed in its representation as neutral.

In any game, the card dealer is (mathematically at least) part of the game, but only the others are called players; in the handling of collective destinies and resources, the card dealer calls "political" those who make use of the cards that politics distributes. The Fascist regime made use of folklore as well 
as of folklorists, inventing festivals, promoting rurality, adopting celebrative routines that make the new order the natural climax of a historical process.

Folklorists obeyed and complied. Some by keeping silent, some by signing most hideous racist laws or accepting most senseless orders. Raffaele Corso, as director of a scholarly journal, after the propaganda decision of expunging from any Anglicism or Gallicism the Italian language, plainly deleted the term "folklore" from the title of the journal, committed to align it (and himself) with the new natural and neutral linguistic order:

To the readers. Starting today, this journal, born in 1925, when the Fascist Revolution was in its full fervency, will leave the name of "Il Folklore italiano" [...] and get the title of Archivio per la raccolta e lo studio delle tradizioni popolari italiane. It is not indeed a brand new name, as our readers were already familiar with it as the subtitle, it takes now a place of honor, owing to the fact that the new culture and the renovated conscience of the Italian people refuses to accept foreign terms in our language. (issue 14: 1-2, 1939; see also Alliegro 2011: 158)

Gianni Vattimo reminded us of that old affiche because he read in it a parallel with the ongoing temptations of "neutralization" of political stances and discourses (Vattimo 2008); I think that the "naturalization" is a good key to get through our topic: critiques are political, power is natural and neutral. The fascist regime was successful in the neutralization of the popular culture, severing its ties with self-determining management procedure, passing from a hierarchy of elected people (the President of Società Filodrammatica - the amateur theater society, or the President of the Philharmonic society - the institutions fathering the marching bands) to a hierarchic order of nominees representative of the central power, from the center and from the top to the periphery. While doing this, the Fascist selected, prohibited, launched, celebrated: folklore was, then, a really appreciated resource, with which to naturalize the presence of the regime in the tiniest unit of social life (Cavazza 1997). Public folklore, made of celebratory events, heavily fascist in their original state, passed as heritage in the following era, cleaned up of its most blatant signal of fascist connotations - away with the fasces, away with Mussolini's silhouettes - under the enduring protection of that artificial "naturalness" and "neutrality".

After the fall of the regime and following the dramatic watershed of World War II, namely the Resistenza and finally the Republican turn, in the more recent times, folklorists could still find it possible to float on that common sense: Raffaele Corso was ready, after restoring the original good Saxon compound to his journal title, as early as 1945, to present an issue celebrating the chants of partisans. Neutral before, neutral after: even if, in the new times, "neutrality" should have become a "position", not an objective condition. 


\section{OBSERVATIONS ON FOLKLORE, THEN AND TODAY}

In reality, it is indeed in that very moment that a deep change in the Italian folklore school is maturing. With the end of the regime, many resources became attainable; the most precious for our discipline was the Prison Notebooks, where Antonio Gramsci, who died in 1937 after several years of fascist prison, noted his thoughts, reflections, projects, and observations (Gramsci 1975) on national culture, on mass and political culture, on common sense, on power relations. Within this vast intellectual project, folklore (or, alternatively, folclore) was the object of some insightful and sharp thoughts, elaborated between 1929 and 1935, and collected as a unitary chapter, The observations on Folklore, in the first edition of the Notebook (Cirese 1976, 2008).

Though disregarded by most of the recent Gramsci's discoverers (even in its English version from 1982), Cirese's analysis of Gramsci's pages shows how the folk was once and for all stripped of every ambiguity: the folk are the instrumental and subaltern classes, no longer the people of the nation, nor the vulgus of complex societies but a sociological and political subject defined by its position in the structuralist scheme - "instrumental", then working class: proletarians, peasants, artisans... This politically defined subject elaborated cultural responses to elemental human needs, making use, in an active and creative way, of what was being produced at the level of higher cultural elaboration, that of aristocratic or religious or bourgeois world visions, discourses, hierarchies, in a condition of political subjection. Political domination could be seen as reflected in the hegemony at the cultural level: its complementary counterpart, the subaltern world view, would be what was known as folklore. As Alberto Cirese made clear (Cirese 1976), Antonio Gramsci didn't think of it in elegiac or idyllic terms. Folklore must be considered as a serious matter: a real conception of the world and life, which has been historically produced in the frame of political conditions of domination. Many threads emerged from Gramsci's suggestions and from his rephrasing of folklore and of the folk: Ernesto de Martino (Saunders 1984; Signorelli 2015; Zinn 2015), for instance, who directed his theoretical interest towards the magic wisdom and focused on the central question of human and social "presence" as the fundamental base for any cultural construction or any social institutions (de Martino 1958, 1959, 1961), identified his privileged interlocutors in the Southern Italian peasant masses. Gramsci's legacy (together with idealistic and historicist remains) fueled his extended fieldwork: all through the 1950s de Martino travelled, recorded and interpreted traditional mourning practices, magic views, reintegration rituals of the masses that had remained excluded by Western civilization's achievements because of their political condition of being the dominated. De Martino wrote that he was entering the houses of southern Italy "as a comrade" (de Martino 
1953) endorsing his responsibility as an intellectual (again Gramsci's precise indication) to help them to "enter into history" and to build a newer and common future. Studying folklore, within such a frame, was a way of making a revolutionary utopia closer and socially inclusive. Practicing ethnology in this way was also, as he stated in a minor but fundamental essay, a way in which the knowledge of peripheral cultures could contribute to enlarge the humanistic horizon that western philosophy had drawn as coincident and congruous with the western and capitalistic economic and political needs (de Martino 1962).

Others were seduced by the idea that within the folklore complex - as well as in practices marked by subalternity (those which the modern common sense felt to be "superstitions", or those inclinations to lyricism that romantics cherished so much) - the folk was elaborating creative answers where seeds or flashes of political conscience could be detected (Bosio 1975; Lombardi Satriani 1974; for criticism see in Solinas 1980 or Cirese 2009). This was a path in search of "progressive folklore", which, early on, took the route of artistic valorization of folk expressive forms and of the provocative aggression towards official culture; in June 1964, Roberto Leydi, Filippo Crivelli, Franco Fortini and the Nuovo Canzoniere Italiano, proposed to a prestigious performing art festival (the Festival dei due mondi, in Spoleto) a performance of labor and political songs under the title of Bella Ciao (Bermani 1997). It was received as a slap in the face by the bourgeois and right-oriented audience who mounted real turmoil (Marini 2005); at the same time it brought to surface the extraordinary vitality of folk music and dramaturgy - that which romantics or nationalists had neglected as contaminated with modernity. The search for progressive culture would thus be yet another step in the theoretical perspective of folklore as a repository of conflictual though politically undeveloped thoughts and sentiments. A generous but utopian wishful view of what Italian popular culture really was. As opposed to that, the first thread soon became absorbed by the market reaction that neutralized it within the folk revival commercial season (1970s-1980s), again separating and dividing the waters of political folk - labor, protest, antimilitarist songs and performances - from neutral folk, the nostalgic, sentimental, witty and even saucy ones that colonized the cultural offer to television massive audiences.

The third, and most enduring thread of Gramsci's thought was woven by Alberto M. Cirese, a folk poetry researcher himself, who developed Gramsci's indications into an epistemology of a renewed folklore theory: from the end of 1960s until the first half of the 1970s, Cirese gathered in his most renowned opus, Cultura egemonica e culture subalterne, the general proposal of folklore study as that part of anthropology dedicated to the cultures that had historically been growing and configuring as differentiated within com- 
plex societies, in the double condition of cultural subalternity and political domination. That difference was a dislivello (difference in height, presented to a European folklore school in the first issue of Ethnologia Europaea Cirese 1967), a metaphor borrowed from the language of fluid mechanics to make clear that folklore materials (rhymes, melodies, objects, thoughts) are not mere differences they occupy in relation to their analogous or homologous items that are part and parcel of the powerful, legitimate, culture. With Cirese's re-elaboration of Gramsci, the haunting questions of where and when folk items originate, become irrelevant: cultural history, using philologically appropriate tools, will deal with these questions specifically; folklorists deal with what they find within the cultural expressions and worldview of the folk they decide to work with.

Folklore then becomes a sub-discipline of anthropology, which has to deal with a processual conception of its object, starting from its positional value, centering on the ethnographic encounter and dialogue and offered to the wider society as a critical contribution to the understanding of the inner dynamics of domination, but also to focus on the creative and proactive answers that are and were historically given to the exclusion of the cultural resources of the dominants classes.

There never was a gene amongst Tuscan peasants that would enable them to extemporize long poetic compositions, or the Sardinian shepherds to sing impromptu word-made laceworks. The origin of that art resided in their exclusion from the literacy processes and resources. The feeling of the poetic potential, and its need, does not depend only on education: those whom it has excluded, may hear, steal, reproduce, adapt, rephrase, reproduce and transmit it through generations. It will always be the result of a political relation, it will always be readable in the frame of power relations.

History was going fast, but in a different direction than that which our Marxist-oriented ancestors had dreamt about; Alberto Cirese himself was rethinking his own scheme and reviewing his passionate adherence to revolutionary perspectives. But his epistemological revolution had been put in motion, and Italian folklore schools has since had - mutatis mutandis - its occasion for a radical theoretical and political turn analogous to Falkenstein (Bendix 1997). It was freed from the obligation of simply collecting items or of celebrating the richness of the nation. From that time on, it could dedicate itself to identify, in the cultural diversity that folklore is reproducing, the practical proof of how concrete the "power forces" may be, and how human possibilities are broader than those that powerful institutions (or economic leading systems) select, legitimate and foster.

Of course, most folklore scholarship has been imported into this new scheme, haunting it with routines and old themes and priorities, which, on the other hand, makes a familiar place of the discipline (Hafstein 2015). As 
already stressed (Mugnaini 2001), Italian folklore scholarship has been paying too much attention to traditions as the product of cultural transmissions from the previous generations than as the process of active selection from the past under the influence of some present and urgent need, such as the construction of meaningful collective practices, coping with modernity and social changes, too often called and invoked as objective and neutral "traditions". So, to give an example from one of the most well-known Italian regions, under the Tuscan sun, we've got an absolute prevailing orientation to celebrating the past (confusing medieval and modern, rural and urban; peasant and aristocratic) and the old fashion peasantry, the mezzadri, the sharecroppers and their culture, notwithstanding the fact that their legacy went under a process of political impoverishment and of progressive marginality from the social and political point of view, until it substantially transubstantiated into Heritage. We - regional ethnographers - have not sufficiently documented how resistant peasants deal with changes and challenges, how they have succeed in their resilience until the present day, meeting and cooperating with new labor policies, how they deal with the emergent role of a sustainable and affordable rural life and economy, together with new peasants and with a possible new role for land-based economy, society and culture.

Fabio Dei (2002) has been saying reproachfully that Italian folklorists failed to work on the workers' culture: blue collar domestic life, discourses, sociability, have simply been left to the quantitative consideration of sociology or to apocalyptic views of a critical philosophy which saw in them the proofs of the alienating power of capitalism. However the final balance of the folklore scholarship of the 1950s to 1980s period is decidedly positive, as epistemological positioning, theoretical growth and political awareness.

It must be said, in addition, that the speed of socio-economic changes in the country played a significant role in the whole process: the working class, who had being emerging and settling as a possible new social force (and as such, exiting from the condition of subalternity as a bearer of an alternative systemic project) started to fade fast, to commute into the tertiary sector; the blue collar class discolored into the white collar. It has been both a process of economic change (deindustrialization and the birth of new-economic sectors) and of social mobility (white collar as a desired goal) but at the same time, residual blue collars and new white collars have been losing much of their original social force (the former) and prestige (the latter).

1989 is a pivotal date, for the fall of the iron curtain implied a vast revision of any political engagement practice (even if the most sensitive part of the communist area had already sharply distanced itself from the "realized socialist" realities). The country, which survived this political turmoil, surrendered to somewhat new forces. The media-based, right permeated and populistic power of the Berlusconi ventennio, inherited an exhausted country, where 
five decades of confrontation between Christian democratic and communist or socialist parties had deeply loosened and weakened each other's credibility and affordability; the so-called "second republic" started emerging as a matter of fact, and was pervaded by neoliberal principles (less state, more market, centrality of the individual against its social ties), although retaining regionalistic and ethnic revivals. Class confrontation, or the Christian social doctrine (both more preached than practiced) were ceasing the scene to a new paradox: the traditional neo-nationalistic rhetoric of the political right against the regionalistic pride or separatist aims of the Northern League administered regions. The contradiction could only be, eventually, overarched by a shared feeling: the xenophobic tendencies that nowadays prevail in that political side and that are, dangerously, in my opinion, starting to seep even into the traditionally left-oriented common discourse.

Wherever a folklorist has been documenting a local or peculiar cultural trait or habits, connecting it to a floating cultural identity, without framing it into a proper historical, sociological and political approach, and giving up, in this way, the holistic approach to culture, someone may have come to claim to be a legitimate heir, foreclosing the legitimacy to others; some way of being may have become "representative", and in this way discriminating cultural diversity and differences just as the effect of the enduring rhetoric force of the "authentic", the "natural" and hence "neutral" folklore legacy. This reinforces the haunting common sense of the neutrality of folklore, and consequently, of its legitimate discipline.

\section{THE TEMPTATIONS OF NEUTRALITY}

While classic documentary and descriptive folklore research continued under the flag of a late romantic and a persisting idealistic approach, the politically oriented approach of the 1960s-1970s did not recognize as a legitimate object of its study any "popular" item that did not fit the utopia of progressive culture; both trends, then, have been converging, in this way, into an indistinct mainstream folklore scholarship, stuck with traditional themes and social subjects. In contrast, public presentation of folklore performances (started in the 1970s with openly political ends) became so successful that many promoters or social actor protagonists of the folklore revival, started to distance themselves from the political reading of their tradition. Benefitting from the successful encounter with television and the market, on the one hand, and amazed by the crisis of militant scholarship on the other, folklore bearers or promoters felt legitimated to refer (partly as a tactic) back to the previous conceptions of folklore as a natural and neutral tradition. Universalistic inclinations, which left-oriented politics brought within 
the valorization of local popular culture, are being replaced by mediatic attention and immanent celebration of local identities; the media attention implies publicity and, soon, advertisement: the market is no longer a social place where folklore has always been circulating amongst other goods and tools. The present growing market is that of cultural stuff: folklore may be produced and sold, may be broadcast and used as instrumental goods to promote other merchandising: from tourism, to food, to political consensus.

It is no longer the case of local entrepreneurship that had, since the 1970s, been giving birth to a lively market of local folklore, where records, books, garments, foods, tools from the area could be purchased; from the 1990s onward, folklore items have been involved in the bigger picture of hegemonic cultural industry: they permeate the everyday life of television viewers, and are, often, the pivot of the tourism sector. Keeping with our main thread - the relation between folklore and politics - it must be noted that the crisis of big political narratives (mostly the communist one) leads to the success of a new political trend: the identity obsession. The need for identity is taken for granted and, of course, as natural, and hence neutral. Anthropologists' voices against it and its essentialist views, or anthropologists' claims that cultural integralism is the return of cultural-based racism, will be neutralized by the same arguments which have always been used against criticism: their contribution is politically biased, while the object of their critique is not, without question.

The Palio of Siena, a feast that is probably familiar to many tourists and Italy (or Tuscany) lovers, has had several readings, of which the most famous by far is the monograph by Alan Dundes and Alessandro Falassi (Dundes and Falassi 1975). What has gone almost unnoticed, however, is how the social structure of the city participates in it and how the political management of the local resources may have been influencing its life (as stated by, for instance, Sydel Silvermann) (Silvermann 1985). But Palio makers and actors themselves, would not accept being studied under such a perspective. The festival institution has been organizing its own discourse, where Palio legacy and identity have been protected from any political reading through the successful merchandising of its images, its artisanal by-products and its tourist appeal, all of which have abridged the real and factual events or dynamics that make its perpetuation possible and meaningful. But this intimate face is not easily accessible or willingly offered to anthropological analysis. Natural, as identity, neutral, as any natural elements are, and esthetically-oriented, what the Palio system and discourse has achieved serves as a model for the widespread movement of medieval festivals which have been growing everywhere (Mugnaini 1997, 2006, 2013).

This is not the first time: back in the 1920s, when the Fascist cultural policies started to support the revival or (if needed) the fabrication of new urban 
festivals in order to use them to condense the passion for social and local life of the fascist-to-be Italian people, the Palio of Siena was actually used as the model to be reproduced (Cavazza 1994, 1997); within the last three decades, and without any directives or centralized guidelines, neo-medievalism has been spreading everywhere, borrowing from it the same undisputed ancestrality and the same ostensible neutrality. This spectacular turn - and I mean medieval festivals, jousts and tournaments, historic commemorations, living Creches or living Passions - are the main part of the current flourishing offer of folklore for public culture consumption, with a few, almost unnoticed, remains of a dividing or different folk cultural tradition.

Tuscany was the place where, despite its economic importance, rural culture was traditionally misconceived up to the point of stigma (Clemente et al. 1980); it is from within this rural culture that some folk dramas have been produced and transmitted for centuries, along with their peculiar esthetic traits, either as theatrical devices or as musical performances. The Tuscan landowners tried to "ennoble" them, suggesting themes or corrections, Fascist intellectuals tried to infuse them with opportunistic ideological content, and to bring them out of the country and into the town to show the power of conviction of the regime; they fade soon after the Second World War, and when the 1970s revivalist go back to them, they are still bearers of a provocative power: in many cases, which I know of personally, people attended the dramatic representation as a revanchist affirmation of their right to be there (i.e. in the public areas of the urban space). This "positional" value will be completely lost and, often, ostensibly erased.

The agency of display (Kirshenblatt-Gimblett 1989) has been incorporated and the active practice of folk artistic skills has been transferred from the position of "dislivello" - different positions in relation to the hegemonic culture to that of mere cultural diversity - often counting on paternalistically overlooking some lapses in good taste.

Such a cleaned-up product is good in several ways: it can be merchandized, it is something that can be offered, projected and planned, transferred, put on shelves; it is something locally owned, often sustained by public funds, in order to generate political interest and to deserve the attention of political cultural institutions. This polished folklore is now also a good example of the latest theoretical turn in the long-lasting history of folklore studies and of folklore handling, that is the heritage turn.

\section{POLISHING FOLKLORE, NEGLECTING PEOPLE}

I will keep the surfing-style of this reflection, and I will skip the by-now overwhelming literature on and from Unesco's intervention in the mater of 
intangible cultural heritage, the story of which has already been told and, moreover, is being actively related by many folklore experts, not necessarily expert folklorists or ethnologists. According to the overarching and universalistic ends of Unesco - and hence certainly neutral - new experts must be familiar with bureaucratic procedures, with redaction (again) of catalogues, of repertories, and be able not to detect the diverging and sometimes disturbing aspects of the past folk heritage, but to rephrase it in a more convenient and decent manner, so as to offer the fruits of dominated groups to the glory of the nation that encompasses them or their region, and, in the end, to the glory of humanity.

The trajectory, as Berardino Palumbo wrote a decade ago, between the bell-tower (il campanile) and the universalistic Unesco's celebration (Palumbo 2003, 2009) passes through the renewal of the mediation of the nation-state - the state party, the minimum entity that may apply for the inscription on the list of intangible cultural heritage - and, of course, of the governing forces, which can select and decide. Then, according to the same process that goes on at the economic and the bureaucratic level, the nationstate cedes part of its sovereignty to the international level, and globalization is once again reaffirmed as the future horizon. At this height, and from this point of view, the socio-political position of the persons who are knowledge bearers is less evident and important than knowledge itself: the latter is objectivated as if it did not derive most of its relevance from the socio-political "connotation" or from its position within the cultural field.

Just a short digressive example: amongst the available expressive means, Tuscan illiterate peasants could count on the poetic genre called "ottava rima", technically mastered as an impromptu oral performance. Two poets, in a public space (a marketplace or an inn), would stage a bravura duel, alternatively creating stanzas on a theme - often suggested by the audience - with a strong commitment to the immediate dialogue with an actual and present social context. Many actors or singers, such as Roberto Benigni or Gianna Nannini, have been playing with it, but always as a "quotation" from the popular culture and a homage to it.

In the last decades, under the flag of heritage, schools of ottava rima have been flourishing; an "Academy" was founded and its promotion in the tourist and high cultural frame was even generously financed; it seemed to have become irrelevant that the Tuscan traditional impromptu poetry (the ottava rima) was represented by a singer such as Niccolino Grassi, a poorly educated shepherd, who still uses it as a device to give voice to his worldview (Niccolino has been a communist and still longs for this utopia) in this way singing about his right to hope for a political change, or by Davide Riondino, a cultured and professional actor (politically leftist as well), who in the course of his career discovered improvised poetry and learnt how to perform it, 
adding it to his already rich palette of professional performance skills. Many other performers, "new" poets, have been studying it, writing and making use of handbooks and teaching at schools for poetic improvisation. The "artistic skills" - the art of singing verses while creating them - is indeed a heritage, and being folk - public - knowledge, the right of those who decided to be its heirs to inherit is undisputable. What has to be reflected on is the striking difference implicit in the socio-cultural frame of its different ways of being performed. Niccolino Grassi, amongst others, has been keeping alive the only way that poetry was available to illiterate people; the new poets have learnt to create it, or to teach it, and may even attain better results; but their right to be its heirs and to represent it on the complex stage of heritage is conditioned by the moral - political - obligation to also support the task of presenting the social conditions and the life opportunities of those from whom they could learn it (see Mugnaini 2009).

While the focus is on the "products", heritage seems to be linked to the past (and Riondino may be worthy of Niccolino Grassi or even better) but if we move our attention to the social and political roots, we are immediately redirected towards the present day, towards youngsters rapping, towards free-style battles, towards the world of marginalities more than towards poetic academies.

The more folklore studies concentrate on folk items, the less they can understand, say and display about its social meanings and political relevance.

It is very easy to miss that point of balance: another example can be found in an admirable work from Piemonte (Cassarin et al. 2009), Riti e cicli festivi nella comunità franco-provenzale di Giaglione in Valle Susa. Giaglione and the Susa valley had already been an object of a seminal essay on feast, peasant cultural heritage and the complexity of the contemporary societies, written by Gian Luigi Bravo in the early 1980s, (Bravo 1984), when he made use of some hints from the Marxist sociologist Luciano Gallino (Bravo 1984). In the new work, this debt is duly acknowledged, but nothing is said about the changes that history brought to the Susa valley.

Not one word is said about the fact that over the valley someone has drawn the layout of a new railroad (Turin - Lyon), apparently urgently needed for European economic development. The (residual) people of the valley rose up against the project, achieving consensus amongst intellectuals, experts, young antagonist movements, anti-global and ecologist forces, so that since the early 1990s the Susa valley has been synonymous with one of the most striking conflicts that have divided the governing forces at the national as well as the regional level from the local collectivities. The communities that local history and folk experts placed at the roots of traditional and ceremonial behaviors (as neutral as a sword dance or shrine machinery holdings may be) have been expressing resistance for more than ten years, to attract 
help and attention, in symbolic acts (like hauling down the Olympic flag in 2006, during the winter Olympic Games in Turin) as well as in concrete conflict organization. All these clashes and this entire political side of life in the Valle Susa during the last twenty years, remains out of the publication which, to use Henry Glassie's words, is good historical work by a well-mannered folklorist.

\section{SE NON CREDETE AL LABBRO MIO, CREDETE A QUESTO GALANTUOMO}

A long time ago, Konrad Köstlin (Köstlin 1996) identified two parts of an alternative that European ethnology had to deal with: either performing (and training) brilliant storytellers to give reassuring and peaceful messages to the European societies, or taking the fact that it is a critical discipline seriously (Mugnaini 2001).

The social life of cultural diversities didn't stop with the celebration of folklore selections operated by nation-states; the totalitarian experience, on both sides of the curtain, showed an enduring efficacy of handling the lore of the folk; dramatic outcomes of the Balkan crisis proved how far "western civilization" (as a whole, not only its Balkan side), our rationally driven and scientific politics, may protect and conceal really inhuman and barbarian behaviors - as de Martino wrote (de Martino 1962: 133-169).

Our societies are constantly moving and changing. It is up to us to decide which position must be taken by folklorists, and what kind of use they can or must make of their power to identify, define and bring to light their own object.

Our societies are changing because of the arrival of migrants: folklorists mostly missed the occasion of treating migration flows when they were impoverishing the poorer areas of the Italian nation; we should not perhaps make the same error twice. What has a Region like Veneto, which has been cultivating folk heritage as a moral duty towards the thousands of its emigrants, to say to or about incoming migrants? What have European ethnologists to say about the blending of people, languages, tastes, that wave after wave, made the Northern people even more familiar - even genetically!- with southern and Mediterranean people? Do we have anything to say about the risks of a recoil on local entities and national repertories? Are we able to incorporate in our updated methods new topics like the Para tot parata (the Everybody's parade, where migrants, refugees, anarchists, students, squatters, queer groups, march and meet the mainstream people, offering foods, artistic performances and music) which has regularly been held in Bologna, thanks to the work and passion of younger generations, often marginal to the 
economic system (the new instrumental classes) or to the official cultural policies (where hegemony still lies)? Can we endorse, with the force of our scientifically-based arguments, the right of homoparental families (Grilli 2016) to march through any Italian town, despite the anathemas of the more traditionalist, right-wing Catholics? Will we be able to record and to read how during the commemoration of the Resistance, in the carelessness of many of the young and adult generations (that consider it an exhausted ritual), it could happen that people from Kosovo who migrated there (I'm referring to a commemoration in a Tuscany hamlet in 2014), brought their food, and shared our and their singing and dancing skills? I was there, as a speaker, and could only take photos of it; let me take this opportunity to share this unexpected piece of ethnography, where the sound memory still holds that surprising version of the most renowned traditional local dance, the polka di Zaccheo. To see it danced by Kosovar men and women, marking their dance steps, reminded me sharply of how anything we hold as our own, is actually lent to us by someone else. The polka that Zaccheo (a local musician) was playing during the local festivals and events, which had been recorded in the 70's and published later on one of the few local folk music records (Toscana. Grosseto, Siena, edited by Centroflog 1980), has entered the official memory of Castelnuovo Berardenga since that recording, but it had already arrived from afar, and from the east.

It is common scientific sense that the Marxist classes no longer exist, that Gramsci's instrumental social forces are no longer recognizable in the present-day social division of labor; the digital world and social webs have been contributing to confusing the scene which the folklorist were accustomed to read and to peek through, but are we certain that the worldview of the generation which is growing to adulthood in "precariousness" is so distant - in the capacity of self-determination - from the subaltern people that de Martino encountered? Reflexively, to remain loyal to the main buzzword of post modernity, could we say to our students, that their power as future intellectuals will be the same as that of our ancestors, or do we also have to prepare them to fight to affirm their right to know and to work as intellectuals, to convince others that an anthropological perspective on the present and past worlds, on cultural diversity, on home - culture differentiation, is necessary to choose the right way to the future, to avoid the already beaten tracks, to gain another level of universalistic comprehension of globalization?

The only novelty that I'm able to concede to the "global" approach is that it shows how very small and limited our planet is, and how restricted the possibilities for a sustainable future on it are.

For this reason nothing can be wasted any more: natural resources or intellectuals' findings. Politics is the level where common resources are 
handled: we can't leave it to self-appointed specialists, shutting ourselves up in a tower of neutral expertise.

It is no longer a question of political engagement in the form of "giving a voice to", or "calling to", as Carl Lindhal (2004) was suggesting, nor is Elliot Oring's claim to neutrality acceptable (Oring 2004); it is time to recognize that "We need critical discourse that is independent of advocacy. We need advocacy that is informed by knowledge of the history of the field, its representational practices and essentially applied character" (KirshenblattGimblett 1988); we have to discuss the neutralistic drift of the heritage turn. Marc Jacobs (2014) did voice his hope of seeing enlisted, alongside folk arts, the heritage of Western world court art (together with African or Asian court arts that have already been listed), and possibly an online network. Completely absent from his view is the fact that between an African court song and Western opera singing, there is a full history of western colonialism, just as between the Bejart choreography of Ravel's Bolero and the dance of tarantata (Apulia's reintegration ritual pivoting on dance therapeutic practice) there is a history of social marginalization and stigmatization of popular behaviors (see Pizza 2016).

Such a flat and acritical conception of heritage - and practice - is so far from the necessary awareness of power relations that, if it should absorb the few intellectual and theoretical resources of an old discipline like folklore, no space would remain to discuss and open to new themes and subjects. The heritage turn is by all indications oriented to replicate a "descent" conception of heritage, instead of that of the "consensus" (and Barbara Kirshenblatt Gimblett simply hints at the disaster that the 'descent' heritage theory could bring) (Kirshenblatt-Gimblett 1988: 151).

Fortunately many critical views and voices (see the recent first 2016 issue of Journal of American Folklore, on Unesco on the ground, edited by Michel Dylan Foster, just to mention the latest) are countering the routinization of an acritical interpretation of the heritage turn and of its chances, and most of those critical voices come from those who have been making ethnography of heritage practices - not simply mumbling on projects or on theoretical principles.

In my answer to the young convenors, I can't but remember that when I chose to study folklore, Gramsci's guidelines were pointing at one precise utopist horizon; somewhere else it has been misled, ideologically, with unbearable state power; this historical mistake doesn't solve the need for an alternative to the status quo that has been nurturing the utopia. That need is even stronger, today, because there is no clearly delineated horizon to watch: al andar se hace camino, (walking reveals the roadmap), wrote Machado: let's be clear about the walking partners we've selected, and let's share with them the heuristic potential of the disciplinary tools; let's be sure 
that our task, as those who work "on" normal people, is to work with them, in a restless search for crumbs of wisdom, of justice, of freedom, of lightness, of frugality, of rescue, in any of the possible cultural expressions they might have encountered.

\section{REFERENCES AND SOURCES}

Alliegro, Enzo Vinicio. 2011. Antropologia italiana. Storia e storiografia, 1969-1975. Firenze: Seid.

Basgoz, Ilhan. 2001. "Folklore and Politics in Turkey, Bawdy Jokes, and Linda Degh". The Journal of American Folklore 114/451: 68.

Bendix, Regina. 1997. In Search of Authenticity. The Formation of Folklore Studies. Madison: University of Wisconsin.

Bermani, Cesare. 1997. Una storia cantata. 1962-1997. Trentacinque anni di vita del Nuovo Canzoniere Italiano/Istituto Ernesto de Martino. Milano: Jaca Book.

Bosio, Gianni. 1975. L'intellettuale rovesciato. Milano: Bella ciao.

Bravo, Gian Luigi. 1984. Festa contadina e società complessa. Milano: Franco Angeli.

Cassarin, Piero, Pier Paolo Giors, Ugo Ponsero, Valentina Porcellana, Giovanni Ponte, Enzo Vayr and Lia Zola. 2009. Riti e cicli festivi nella comunità francoprovenzale di Giaglione in Val di Susa. Scarmagno: Priuli \& Verlucca.

Cavazza, Stefano. 1987. "La folkloristica italiana e il fascismo. Il Comitato Nazionale per le Arti Popolari”. La Ricerca Folklorica 15: 109-122. [http://dx.doi.org/10.2307/1479492]

Cavazza, Stefano. 1994. "Il Palio e le tradizioni popolari senesi durante il fascismo". Fascismo e antifascismo nel senese. Atti del convegno. Siena, 10-11 dicembre 1993. Alessandro Orlandini, ed. Firenze: Edizione Regione Toscana, 265-284.

Cavazza, Stefano. 1997. Piccole patrie. Feste popolari tra regione e nazione durante il fascismo. Bologna: Il Mulino.

Cirese, Alberto Mario. 1967. "Altérité et dénivellement culturels dans les sociétés dites supérieures". Ethnologia Europaea 1: 12-29.

Cirese, Alberto Mario. 1971. Cultura egemonica e culture subalterne. Rassegna degli studi sul mondo popolare tradizionale. Palermo: Palumbo

Cirese, Alberto Mario. 1974. "Folklore in Italy. A Historical and Systematic Profile and Bibliography". Journal of the Folklore Institute 11/1-2: 7-79. [http://dx.doi.org/10.2307/3813941]

Cirese, Alberto Mario. 1976. Intellettuali, folklore, istinto di classe. Note su Verga, Deledda, Scotellaro, Gramsci. Torino: Einaudi.

Cirese, Alberto Maria [sic]. 1982. Gramsci's Observations on Folklore. Showstack Sassoon, A. Approaches to Gramsci. London: Writers and Readers, 212-247.

Cirese, Alberto Mario. 2009. “Gramsci ritrovato tra Cirese e I Cultural Studies (24-25 ottobre 2008)", transcribed speech. Lares 74/2: 321-425.

Clemente, Pietro, Mirna Coppi, Gianna Fineschi, Mariano Fresta and Vera Pietrelli. 1980. Mezzadri, letterati e padroni nella Toscana dell'Ottocento. Palermo: Sellerio.

Conrad, JoAnn. 1998. “The Political Face of Folklore. A Call for Debate". The Journal of American Folklore 111/442: 409-413. 
De Martino, Ernesto. 1952. “Gramsci e il folklore”. Il Calendario del Popolo 8/91: 1109. In Clemente, Pietro, Maria Luisa Meoni and Massimo Squllacciotti. 1976. Il dibattito sul folklore in Italia. Milano: Edizioni di Cultura Popolare.

De Martino, Ernesto. 1953. "Etnologia e cultura nazionale negli ultimi dieci anni". Società 9/3.

De Martino, Ernesto. 1958. Morte e pianto rituale nel mondo antico. Dal lamento pagano al pianto di Maria. Torino: Boringhieri.

De Martino, Ernesto. 1959. Sud e magia. Torino: Boringhieri.

De Martino, Ernesto. 1961. La terra del rimorso. Contributo ad una storia religiosa del Sud. Milano: Il Saggiatore.

De Martino, Ernesto. 1962. Furore, simbolo, valore. Milano: Feltrinelli.

Dégh, Linda. 1999. "Politics alive in Turkish Folklore". The Journal of American Folklore 112/446: 527-528. [http://dx.doi.org/10.2307/541488]

Dei, Fabio. 2002. Beethoven e le mondine. Ripensare la cultura popolare. Roma: Meltemi.

Dundes, Alan and Alessandro Falassi. 1975. La Terra in Piazza. An Interpretation ofthe Palio of Siena. Berkeley, Los Angeles: University of California Press.

Glassie, Henry. 1982. Passing the time in Ballymenone. Culture and History of an Ulster Community. Bloomington, Indianapolis: Indiana University Press.

Gencarella, Stephen Olbrys. 2009. "Constituting Folklore. A Case for Critical Folklore Studies". The Journal of American Folklore 122/484: 172-196. [http://dx.doi.org/10.1353/ jaf.0.0086]

Gencarella, Stephen Olbrys. 2010. "Gramsci, Good Sense, and Critical Folklore Studies”. Journal of Folklore Research 47/3: 221-252. [http://dx.doi.org/10.2979/jfolkrese.2010.47.3.221]

Gencarella, Stephen Olbrys. 2011. "Folk Criticism and the Art of Critical Folklore Studies". Journal of American Folklore 124/494: 251-271. [http://dx.doi.org/10.5406/jamerfolk.124.494.0251]

Graham, Brian and Sara McDowell. 2007. "Meaning in the Maze. The Heritage of Long Kesh". Cultural Geographies 14/3: 343-368. [http://dx.doi.org/10.1177/1474474007078204]

Gramsci, Antonio. 1975. Quaderni del carcere. Valentino Gerratana, ed. Torino: Einaudi. [http://dx.doi.org/10.1590/s0101-31731975000100011]

Grilli, Simonetta. 2016. “'D’autres familles'. L'homoparentalité en Italie”. Ethnologie Française 47/2: 289-298.

Jacobs, Marc. 2014. "Bruegel and Burke were Here! Examining the Criteria Implicit in the UNESCO Paradigm of Safeguarding ICH: The First Decade". International Journal of Intangible Heritage 9: 100-118.

Hafstein, Valdimar Tr. 2015. "Haunted Places". Ethnologia Europaea/Journal of European Ethnology 44/2: 113-115.

Kirshenblatt-Gimblett, Barbara. 1988. "Mistaken Dichotomies". Journal of American Folklore 101/400: 140-15. [http://dx.doi.org/10.2307/540105]

Kirshenblatt-Gimblett, Barbara. 1998. Destination Culture. Tourism, Museums, and Heritage. Berkeley: University of California Press.

Köstlin, Knorad. 1996. "Perspectives of European Ethnology". Ethnologia Europeaea 26/2: 169-180.

Lindahl, Carl. 2004. "Afterword". Journal of Folklore Research 41/2: 173-180. [http://dx.doi. org/10.1353/jfr.2005.0007] 
Lombardi Satriani, Luigi M. 1974. "Folklore as Culture of Contestation". Journal of the Folklore Institute 11/1-2: 99-121. [http://dx.doi.org/10.2307/3813943]

Marini, Giovanna. 2005. Una mattina mi son svegliata. La musica e le storia di un'Italia perduta. Milano: Rizzoli.

Mugnaini, Fabio. 1997. "Karneval bez korizme, tradicija bez prošlosti. Karneval i ostale svetkovine u Sieni i okolici". Narodna umjetnost 34: 167-182.

Mugnaini, Fabio. 2001. "Introduzione. Le tradizioni di domani". In Oltre il folklore. Tradizioni popolari e antropologia nella società contemporanea. Pietro Clemente and Fabio Mugnaini, eds. Roma: Carocci, 11-72.

Mugnaini, Fabio. 2006. "Medieval Ever Since, Medieval Forever. A Survey on the Return of the Past in Present day Urban Festivals in Italy (and Elsewhere)". In The Past in the Present. A Multidisciplinary Approach. Fabio Mugnaini, Pádraig Ó Héalaí and Tok Thompson, eds. Firenze, Catania: Edit, 267-290.

Mugnaini, Fabio. 2009. "Improvvisazione, tradizione e patrimonio". In Improvvisar cantando. Atti dell'incontro di studi sulla poesia estemporanea in ottava rima. Corrado Barontini and Paolo Nardini, eds. Grosseto: Effigi, 49-68.

Mugnaini, Fabio. 2013. "Le feste neo-medievali e le rievocazioni storiche contemporanee tra storia, tradizione e patrimonio". Lares 79/2-3: 131-158.

Oring, Elliot. 2004. "Folklore and Advocacy". Journal of Folklore Research 41/2: 259-267. [http://dx.doi.org/10.1353/jfr.2005.0011]

Palumbo, Berardino. 2003. L'Unesco e il campanile. Antropologia, politica e beni culturali nella Sicilia orientale. Roma: Meltemi.

Palumbo, Berardino. 2009. "Patrimonializzare". AM 8/22: 38-40.

Pizza, Giovanni. 2015. Il Tarantismo oggi. Antropologia, politica, cultura. Roma: Carocci.

Rihtman-Auguštin, Dunja. 2004. Ethnology, Myth and Politics. Anthropologizing Croatian Ethnology. Jasna Capo Zmegac, ed. Aldershot: Ashgate.

Rithman-Auguštin, Dunja. 2015. Incontro con Dunja Rihtman-Auguštin. Siena, march, 22nd 2000. Laboratorio Audiovisivi ed Archivio "Alberto M. Cirese". Siena: Dipartimento Scienze Sociali, Politiche e Cognitive, Università di Siena.

Sanuders, George. 1984. "Contemporary Italian Cultural Anthropology". Annual Review of Anthropology 13: 447-466. [http://dx.doi.org/10.1146/annurev.an.13.100184.002311]

Signorelli, Amalia. 2015. Ernesto de Martino. Teoria antropologia e metodologia della ricerca. Roma: L'Asino d'oro.

Silvermann, Sydel. 1985. "Towards a Political Economy of Italian Competitive Festivals". Ethnologia Europaea 15: 5-103.

Solinas, Pier Giorgio. 1985. Idealismo, marxismo, strutturalismo. In Pietro Clemente, Alba Rosa Leone, Sandra Puccini, Carlo Rossetti and Pier Giorgio Solinas. Bari: Laterza, 205-264.

Vattimo, Gianni. 2008. "La politica messa fuori gioco". La Stampa, 19-08-2008.

Zinn, Dorothy. 2015. “A Introduction to Ernesto de Martino's Relevance for the Study of Folklore". Journal of American Folklore 128/507: 3-17. [http://dx.doi.org/10.5406/jamerfolk.128.507.0003] 


\section{UKLETA DISCIPLINA: O POLITIČKOJ NARAVI FOLKLORA I POLITIČKOJ SUDBINI NJEGOVA PROUČAVANJA}

U radu se, na temelju talijanskih primjera, bavim tvrdokornom idejom da je folklor objektivan i zadan skup kulturnih izraza. Ta ideja proganja folkloristiku od njezinih početaka tijekom romantizma, a bila je karakteristična i za korištenje folklora tijekom totalitarnih režima. Ipak, od druge polovice prošlog stoljeća, u folkloristici se javljaju novije perspektive, koje se temelje na usustavljivanju Gramscijeva nasljeđa u kojem se na otvoren način govori o društveno-političkoj naravi folklora, a samim time i o političkoj relevantnosti znanstvenih pristupa koji se njime bave. Taj se poseban pristup mora nanovo učvrstiti iz današnje pozicije, kako bismo se uhvatili ukoštac s povratkom iskušenja neutralnosti koje se javlja u suvremenom obratu prema bavljenju baštinom.

Ključne riječi: Gramscijevo nasljeđe, kulturni obrat prema bavljenju baštinom, angažirana folkloristika, politički pristup, talijanska folkloristika 